УДК 631.527:633.11, DOI 10.31210/visnyk2018.04.09

(C) 2018

Мостіпан М. І., кандидат біологічних наук

Центральноукраїнський національний технічний університет

Умрихін Н. Л., кандидат сільськогосподарських наук

Інститут сільського господарства Степу НААН

\title{
ВРОЖАЙНІСТЬ ПШЕНИЦІ ОЗИМОЇ ЗАЛЕЖНО ВІД ПОГОДНИХ УМОВ У РАННЬОВЕСНЯНИЙ ПЕРІОД В УМОВАХ ПІВНІЧНОГО СТЕПУ УКРАЇНИ
}

\author{
Рецензент - доктор сільськогосподарських наук, професор П. В. Писаренко
}

Тривалими польовими дослідженнями доведено, щзо в північному Степу Украӥни чим пізніше відновлюється весняна вететація озимої пшениці, тим меншою є врожайність. При изьому час відновлення вететаиії має значний вплив на врожайність різновікових посівів. У разі надраннього відновлення вететації (III декада лютого) врожайність посівів з сівбою у період з кіния серпня до початку жовтня є майже однаковою і становить від 6,44 до $6,96 \mathrm{~m} / 2 a$. У випадку пізнього відновлення вететації (початок квітня) найбільи високу врожайність формують посіви з сівбою з 10 по 25 вересня. Їх врожайність у середньому за роки досліджень становила 3,86-3,91 m/2a. Чим коротшим є період від переходу температури через $0^{0} \mathrm{C}$ до $+5^{\circ} \mathrm{C}$, тим більшою є врожайність озимої пшениці. У середньому за роки досліджень врожайність озимої пшениці за тривалості періоду від переходу температури через $0{ }^{0} \mathrm{C}$ до $+5{ }^{\circ} \mathrm{C}$ до 10 днів становила 6,04 m/2а, а в разі подовження изього періоду до 30 і більше днів зменшувалася до 3,76 m/2а.

Ключові слова: озима пшениия, урожайність, строки сівби, час відновлення весняної вететації, погодні умови.

Постановка проблеми. Ріст та розвиток рослин озимої пшениці, як і решти представників озимих культур, відбувається у всі пори року. Тому за тривалістю періоду вегетації серед польових культур рослини озимої пшениці посідають одне 3 перших місць залежно від ряду агротехнічних та погодних факторів. Тривалий період вегетації рослин озимої пшениці має як позитивні, так і негативні сторони. Перш за все, це дає змогу рослинам синтезувати більшу кількість органічних речовин у процесі фотосинтезу, порівняно з рослинами ранніх ярих зернових колосових культур. Важливим є також те, що певні втрати врожаю, викликані несприятливими погодними умовами у попередньому періоді, певною мірою можуть бути компенсовані на наступному етапі росту та розвитку рослин. Іншими словами, рослини озимої пшениці мають значно ширші компенсаторні механізми втрат врожаю, порівняно 3 рослинами ярого типу розвитку.

Але в кожному із періодів росту рослин озимої пшениці в умовах північного Степу України проявляється ряд факторів, які мають негативний вплив на формування врожаю. Найбільш небезпечними явищами є посухи в осінній, весняний та літній періоди, а взимку комплекс несприятливих чинників, що можуть викликати повну або часткову загибель посівів озимої пшениці [10]. Наслідки дії цих негативних факторів можуть проявлятися до середини весняного або ж навіть початку літнього періодів.

3 точки зору формування агроценозу посівів озимої пшениці, надзвичайно важливе значення мають погодні умови осіннього та весняного періодів. Дослідженнями авторів доведено, що в умовах північного Степу України найбільш висока врожайність озимої пшениці досягається за умови, коли кількість продуктивних колосів на $1 \mathrm{~m}^{2}$ на час збирання врожаю становить від 500 до 650 штук.

Відомо, що щільність посівів озимої пшениці формується впродовж осіннього та весняного періодів. Оптимальні параметри посівів на час припинення осінньої вегетації, за даними авторів статті, - 750-1200 стебел на $1 \mathrm{~m}^{2}$. Як надмірне загущення, так і зрідження стеблостою може вести до певних втрат врожаю. За сприятливих умов щодо вологозабезпечення факторами, що впливають на щільність посівів на час припинення осінньої вегетації, є строки сівби, попередники та використання добрив чи рістрегулюючих речовин $[9,13]$. Але за умови розміщення посівів по одному попереднику та в разі використання рівноцінного рівня мінерального живлення рослин головним чинником $є$ строк сівби.

У ранньовесняний період всі посіви озимої пшениці перебувають під впливом однакових погодних умов. Але при цьому у посівах різної щільності протікають протилежні процеси, що впливають на щільність продуктивного стебло- 


\section{СІЛЬСЬКЕ ГОСПОДАРСТВО. РОСЛИННИЦТВО}

стою на час збирання озимої пшениці. У щільних посівах відбувається відмирання вже сформованих з осені пагонів, а у зріджених - навпаки, додаткове їх утворення. Інтенсивність таких процесів значною мірою залежить від погодних умов у ранньовесняний період [14].

Аналіз останніх досліджень і публікацій, у яких започатковано розв'язання проблеми. Погодні умови весняного періоду вегетації озимої пшениці є надзвичайно важливими для формування іiі врожаю. Залежно від того, коли розпочинається весняна вегетація рослин та за яких умов температурного режиму та зволоження буде вона протікати, залежить не лише кількість зібраного врожаю, а й його якісні показники. В. Д. Мединець вперше в Україні виявив та обгрунтував істотний вплив часу відновлення весняної вегетації на продуктивність посівів озимої пшениці [2]. Ним також запропоновано заходи підвищення якісних показників зерна озимої пшениці та забезпечення рівня стабільності урожайності залежно від часу відновлення весняної вегетації [3, 4]. У подальших своїх публікаціях В. Д. Мединець переконує в тому, що саме характер та особливості погодних умов на початку відновлення весняної вегетації рослин озимої пшениці $є$ вирішальними у формуванні продуктивності їх посівів [5].

Надалі значний внесок у розвиток цього наукового напряму зробили такі вчені як I. Т. Нетіс $[11,12]$, Браженко І. П., Гангур В. В. та інші [1]. Сорокадворічні результати досліджень вказаних авторів дали змогу їм провести більш детальну класифікацію термінів відновлення вегетації рослин озимої пшениці для умов Полтавщини. Більш того, вони стверджують, що час відновлення весняної вегетації рослин озимої пшениці зумовлюється циркуляцією теплих чи холодних атмосферних мас повітря, а не висотою Сонця на небосхилі. Вчені наголошують, що за різних термінів відновлення вегетації виникають різні можливості у рослин озимої пшениці щодо забезпечення їх елементами грунтового та повітряного живлення. За раннього відновлення вегетації рослини краще забезпечені основними факторами життя, ніж у випадку пізнього.

У північному Степу України умови вологозабезпечення впродовж весняно-літнього періоду вегетації значною мірою визначають їх врожайність. Попередні результати досліджень свідчать, що врожайність озимої пшениці після чорного пару найбільшою мірою залежить від вмісту продуктивної вологи у грунті на час відновлення весняної вегетації та на початку трубкування рослин.
Частка впливу запасів продуктивної вологи у грунті у ці періоди на врожайність озимої пшениці по чорному пару становить 39,7 та 42,1\% для посівів з сівбою 25 серпня, 55,2 та 24,8\% для посівів з сівбою 10 вересня та 36,3 і 33,8 \% для посівів 3 сівбою 25 вересня. Посіви озимої пшениці після гірших попередників є більш залежними від запасів продуктивної вологи у грунті на час відновлення весняної вегетації. Частка впливу запасів вологи у грунті на час відновлення весняної вегетації на формування врожаю досягає 49,7-66,4 \%. При цьому переміщення термінів сівби з 25 серпня на 25 вересня посилює залежність таких посівів від вмісту продуктивної вологи у грунті на час відновлення весняної вегетації та зменшує їх залежність від вмісту продуктивної вологи у грунті у фазу колосіння $[8,6]$.

Більше того, умови ранньовесняного періоду та стан посівів визначають подальший догляд за посівами озимої пшениці. Строки проведення ранньовесняних підживлень та норми використання азотних добрив залежать від часу відновлення весняної вегетації та щільності посівів тобто їх потенційних можливостей $[7,15]$.

Мета дослідження - розробити науковометодологічні основи для впровадження та корегування еколого-адаптивних технологій вирощування пшениці озимої в північному Степу України залежно від часу відновлення весняної вегетації та погодних умов впродовж ранньовесняного періоду вегетації рослин.

Завдання дослідження - визначити вплив часу відновлення весняної вегетації та погодних умов впродовж ранньовесняного періоду на врожайність пшениці озимої.

Методика проведення досліджень. Польові дослідження проводилися у період з 1986 по 2006 роки на Кіровоградській дослідній станції (нині Інститут сільського господарства Степу НААН). Озиму пшеницю висівали після чорного пару у різні строки сівби, починаючи 325 серпня по 2 жовтня 3 інтервалом 6-7 днів. Технологія вирощування розроблена у Кіровоградській державній сільськогосподарській дослідній станції.

Грунти дослідної ділянки - чорноземи звичайні середньогумусні важкосуглинкові глибокі, яким характерний дуже глибокий гумусний профіль (80-100 см) зі значною глибиною гумусного горизонту (40-50 см) та добре виявленою зернистою структурою, яка поступово до низу переходить у зернисто-дрібно-грудочкувату. Вміст гумусу становить 4,54 \%. Вміст рухомих форм поживних речовин в грунті становить 14,5 мг гідролізованого азоту, 12,1 мг фосфору та 15,7 мг калію на 100 г грунту. 


\section{СІЛЬСЬКЕ ГОСПОДАРСТВО. РОСЛИННИЦТВО}

Сума ввібраних основ становить 39,4 мг на 100 г грунту, $\mathrm{pH}$ сольове - 5,6. Клімат в зоні проведення досліджень - помірно-континентальний. Середня річна температура повітря, за даними Кіровоградської метеостанції, дорівнює плюс $7,9^{\circ} \mathrm{C}$, а річна сума атмосферних опадів становить 474 мм, основна кількість яких випадає 3 травня по вересень. Безморозний період триває 164 дні.

У роки проведення досліджень погодні умови в основному були типовими для зони. Водночас у кожному із років відмічені відхилення як за показниками температурного режиму повітря, так і за кількістю опадів. Середньодобова температура повітря впродовж весняно-літнього періоду вегетації рослин озимої пшениці за роки досліджень склала $15,9{ }^{\circ} \mathrm{C}$ зі змінами від $13,4{ }^{\circ} \mathrm{C}$ у 1990 році до $18,1{ }^{\circ} \mathrm{C}$ у 1996 році. Кількість опадів впродовж весняно-літньої вегетації також різнилася у роки досліджень. У середньому за роки досліджень випало 182 мм опадів за період від часу відновлення весняної вегетації до твердої стиглості зерна озимої пшениці. Проте у 1996 році за цей період випало лише 61 мм опадів, що майже втричі менше середнього показника за роки досліджень і в 5 разів менше найбільшої кількості опадів, що випали за роки досліджень у 1997 році (318 мм.).

Тому тривалість весняної-літньої вегетації рослин озимої пшениці суттєво різнилася у роки проведення досліджень. У середньому за роки досліджень вона становила 118 днів. У посушливі роки на фоні підвищеного температурного режиму тривалість весняно-літньої вегетації скорочувалася, а у роки з достатнім вологозабезпеченням - навпаки, подовжувалася. Так, в посушливому 1996 році вона скоротилася до 101 дня, а у помірно зволоженому із відносно низьким температурним режимом повітря 1990 році вона склала 148 днів.

Результати дослідження. Роки проведення досліджень характеризувалися різними термінами відновлення весняної вегетації рослин озимої пшениці. Найбільш раннє (22 лютого) спостерігалося у 1990 році, а найбільш пізнє (4 квітня) у 2003 році. Тому для умов північного Степу України запропоновано виділяти надранне відновлення вегетації (третя декада лютого), раннє (перша - друга декада березня), середнє (третя декада березня) та пізнє (перша декада квітня). За весь період спостережень надранне відновлення вегетації відбувалося у 1989, 1990 та 1995 роках, раннє - 2001, 2002, 2004 та 2005 роках, середнє - 1986, 1988, 1992, 1994, 1997, 1998, 1999 та 2000 роках, пізне - 1987, 1991, 1993, 1996 та 2003 роках.

Аналіз показників урожайності озимої пшениці свідчить, що чим пізніше відбувається відновлення весняної вегетації, тим меншою $є$ врожайність озимої пшениці. За надраннього відновлення весняної вегетації у третій декаді лютого формується врожайність удвічі більша, порівняно 3 пізнім відновленням у першій декаді квітня. У середньому за роки досліджень ці показники становили відповідно 6,74 та 3,28 т/га (рис. 1).

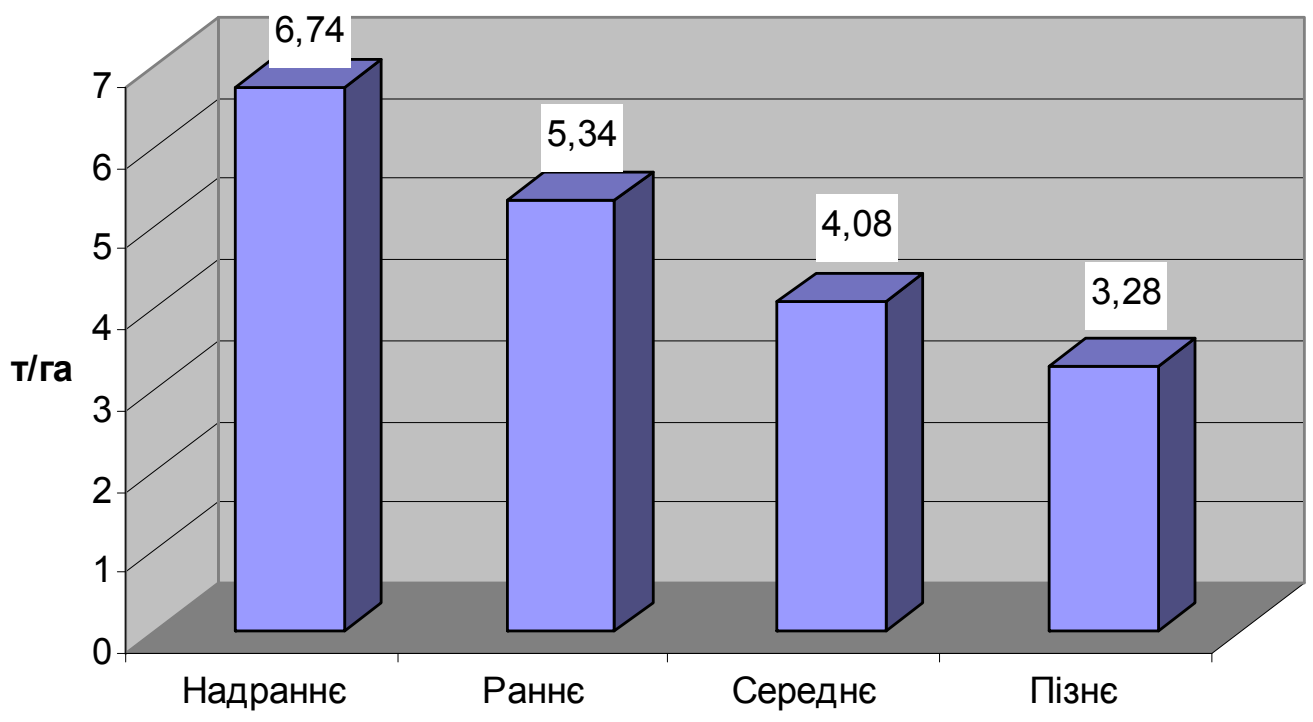

\section{1. Вплив часу відновлення вететації на врожайність озимої пщениці по чорному пару (1986-2005 pp.)}




\section{СІЛЬСЬКЕ ГОСПОДАРСТВО. РОСЛИННИЦТВО}

Вплив часу відновлення весняної вегетації на врожайність озимої пшениці значною мірою залежить від строків сівби. Під час відновлення вегетації у третій декаді лютого врожайність озимої пшениці майже не залежить від строків сівби і змінюється у незначних межах від 6,44 до 6,96 т/га. За таких умов посіви пізніх строків сівби можуть компенсувати недобір врожаю, викликаний недостатньою кущистистю рослин в осінній період вегетації. У посівах пізніх строків сівби за раннього відновлення весняної вегетації відбувається інтенсивне кущення рослин і на початку трубкування щільність посівів різко підвищується. Посіви ранніх та надранніх строків сівби, відповідно, 2 вересня та 25 серпня за таких умов можуть повніше реалізувати свої потенційні можливості (табл. 1).

Отримані результати дають змогу стверджувати, що чим пізніше відбувається відновлення весняної вегетації рослин озимої пшениці, тим чіткіше проявляється дія строку сівби. Так, за раннього відновлення вегетації врожайність посівів озимої пшениці, сівба яких проведена у період 310 вересня по 2 жовтня, залишається високою і становить від 5,41 до 6,02 т/га. Зниження врожайності спостерігається лише у посівів 3 сівбою 25 серпня та 2 вересня. За пізнього відновлення вегетації найбільш високу врожайність забезпечують посіви з сівбою у період з 10 по 25 вересня і врожайність їх становить 3,86-3,91 т/га. Але за такого відновлення вегетації різко зменшується врожайність як 3 ранніми, так і пізніми термінами сівби. У варіантах 3 сівбою 25 серпня та 2 вересня врожайність зменшилася до рівня 2,23-2,92 т/га, а в разі пізньої сівби 2 жовтня до 2,88 т/га.

Пізнє відновлення вегетації викликає зниження рівня врожайності посівів озимої пшениці не залежно від термінів їх сівби, але особливо небезпечним $є$ для надранніх посівів озимої пшениці з сівбою 25 серпня та пізніх посівів 3 сівбою 2 жовтня. Врожайність надранніх посівів за таких строків відновлення весняної вегетації знижується більше ніж утричі, а пізніх - у 2,2 раза, порівняно 3 відновленням вегетації у третій декаді лютого. Врожайність посівів 3 сівбою 25 серпня зменшується 3 6,72 до 2,23 т/га, а посівів 3 сівбою 2 жовтня - 3 6,64 до 2,88 т/га. За пізнього відновлення вегетації існує велика ймовірність повної загибелі таких посівів у ранньовесняний період або ж їх значене зрідження.

Особливою виявляється поведінка різновікових посівів озимої пшениці за раннього відновлення весняної вегетації у першій декаді березня. Найбільш висока врожайність формується за сівби 17 та 25 вересня і становить, відповідно, 6,02 та 5,90 т/га. Саме за такого часу відновлення вегетації період оптимальних строків сівби озимої пшениці виявляється найвужчим. При цьому посіви з сівбою 2 жовтня є більш продуктивнішими, ніж посіви 3 сівбою 25 серпня і навіть 3 сівбою 2 вересня. Врожайність посівів сівба яких проведена 2 жовтня, становить 5,41 ц/га, а посівів 3 сівбою 2 вересня - 4,73 ц/га. При більш пізнішому відновленні вегетації посіви 3 сівбою 2 жовтня за рівнем врожайності поступаються посівам озимої пшениці, сівба яких проведена 2 вересня.

Між рівнем врожайності озимої пшениці та часом переходу середньодобової температури повітря через $0{ }^{0} \mathrm{C}$ також існує пряма залежність. Чим пізніше відбувається перехід середньодобової температури через $0{ }^{0} \mathrm{C}$, тим меншою формується врожайність. Так, у середньому за роки досліджень в разі переходу середньодобової температури повітря через $0{ }^{0} \mathrm{C}$ у другій декаді лютого врожайність озимої пшениці становила 5,26 ц/га проти 3,30 ц/га, якщо такий перехід відбувався у третій декаді березня.

При цьому чим пізніше відбувається перехід середньодобової температури через $0{ }^{0} \mathrm{C}$, тим більшою $є$ залежність врожаю озимої пшениці від строків сівби. Оптимальні терміни не лише звужуються, а й певною мірою зміщуються у бік ранніх (табл. 2).

У роки 3 раннім переходом середньодобової температури повітря через $0{ }^{0} \mathrm{C}$ у другій декаді лютого найбільш високу врожайність забезпечували посіви 3 сівбою 32 по 25 вересня і вона становила у межах 5,36-5,38 т/га. До того ж врожайність надранніх посівів 3 сівбою 25 серпня та пізніх 2 жовтня була майже однаковою і становила, відповідно, 4,96 та 5,08 т/га. У роки 3 пізнім (у третій декаді березня) настанням середньодобової температури повітря вище $0{ }^{0} \mathrm{C}$ найбільшу врожайність забезпечують посіви 3 сівбою 10 та 17 вересня. Їх врожайність становила у середньому відповідно 4,26 та 4,15 т/га. За таких умов найменшу врожайність забезпечували посіви 3 сівбою 2 жовтня i вона становила 2,34 т/га, що на 5,44 ц/га менше, порівняно 3 сівбою 2 вересня та 2,0 ц/га, порівняно 3 сівбою 25 серпня.

Для формування врожаю озимої пшениці важливе значення мають не лише строки переходу середньодобової температури через $0{ }^{0} \mathrm{C}$, а й тривалість періоду від цього часу до відновлення весняної вегетації, тобто стійкого підвищення середньодобової температури повітря понад $+5{ }^{0} \mathrm{C}$ (табл. 3). 
1. Вилив часу відновлення весняної вететації на врожайність різновікових посівів озимої пшениці, $m / 2 a(1986-2005$ pp. $)$

\begin{tabular}{|c|c|c|c|c|c|c|}
\hline \multirow{2}{*}{ ЧВВВ } & \multicolumn{6}{|c|}{ Строк сівби } \\
\cline { 2 - 7 } & 25. VIII & 02. IX & 10. IX & 17. IX & 25. IX & 02. X \\
\hline $\begin{array}{c}\text { Надраннє } \\
\text { (ІІІ декада } \\
\text { лютого) }\end{array}$ & 6,72 & 6,96 & 6,77 & 6,81 & 6,76 & 6,44 \\
\hline $\begin{array}{c}\text { Раннє (I дека- } \\
\text { да березня) }\end{array}$ & 4,40 & 4,73 & 5,55 & 6,02 & 5,90 & 5,41 \\
\hline $\begin{array}{c}\text { Середнє } \\
\text { (ІІІ декада } \\
\text { березня) }\end{array}$ & 3,49 & 3,97 & 4,43 & 4,48 & 4,41 & 3,73 \\
\hline $\begin{array}{c}\text { Пізнє (І дека- } \\
\text { да квітня) }\end{array}$ & 2,23 & 2,92 & 3,91 & 3,91 & 3,86 & 2,88 \\
\hline
\end{tabular}

2. Вилив терміну переходу середньодобової температури через $0^{\circ} \mathrm{C}$ на врожайність озимої пшениці, m/2а (1986-2005 pp.)

\begin{tabular}{|c|c|c|c|c|c|c|c|}
\hline \multirow{2}{*}{ Термін } & \multicolumn{6}{|c|}{ Строк сівби } & \multirow{2}{*}{ Середнє } \\
\hline & 25.VIII & 02. IX & 10. IX & 17. IX & 25. IX & 02. X & \\
\hline $\begin{array}{c}\text { Друга } \\
\text { декада } \\
\text { лютого }\end{array}$ & 4,98 & 5,36 & 5,37 & 5,38 & 5,37 & 5,08 & 5,26 \\
\hline $\begin{array}{c}\text { Третя } \\
\text { декада } \\
\text { лютого }\end{array}$ & 4,36 & 4,86 & 5,23 & 5,47 & 5,63 & 5,12 & 5,12 \\
\hline $\begin{array}{l}\text { Перша } \\
\text { декада } \\
\text { березня }\end{array}$ & 4,26 & 4,23 & 4,81 & 4,88 & 4,71 & 3,88 & 4,46 \\
\hline $\begin{array}{c}\text { Друга } \\
\text { декада } \\
\text { березня }\end{array}$ & 2,93 & 4,15 & 4,68 & 5,01 & 4,99 & 4,61 & 4,39 \\
\hline $\begin{array}{c}\text { Третя } \\
\text { декада } \\
\text { березня }\end{array}$ & 2,54 & 2,88 & 4,26 & 4,15 & 3,63 & 2,34 & 3,30 \\
\hline
\end{tabular}

3. Вилив тривалості періоду від переходу середньодобової температури через $0{ }^{\circ} \mathrm{C}$ до відновлення весняної вететації на врожайність озимої пшениці, m/2а (1986-2005 pp.)

\begin{tabular}{|c|c|c|c|c|c|c|c|}
\hline \multirow{2}{*}{ Днів } & \multicolumn{6}{|c|}{ Строк сівби } & \multirow{2}{*}{ Середнє } \\
\hline & 25.VIII & 02. IX & 10. IX & 17. IX & 25. IX & 02. X & \\
\hline до 10 & 5,06 & 5,45 & 6,47 & 6,88 & 6,80 & 5,56 & 6,04 \\
\hline $10-20$ & 3,73 & 4,11 & 4,78 & 4,73 & 4,68 & 4,03 & 4,34 \\
\hline $20-30$ & 2,80 & 3,88 & 4,37 & 4,99 & 5,28 & 4,70 & 4,34 \\
\hline більше 30 & 2,48 & 3,15 & 4,05 & 4,52 & 4,36 & 3,99 & 3,76 \\
\hline
\end{tabular}

Збільшення тривалості періоду від дати переходу середньодобової температури повітря через $0{ }^{0} \mathrm{C}$ до відновлення весняної вегетації рослин викликає зниження врожайності озимої пшениці. У роки, коли тривалість цього періоду становила до 10 днів, врожайність озимої пшениці у середньому становила 6,04 т/га, а у роки 3 довжиною цього періоду понад 30 днів вона зме- ншилася до 3,76 т/га.

Отримані результати досліджень переконують, що чим коротшим $\epsilon$ період від переходу середньодобової температури повітря через $0{ }^{\circ} \mathrm{C}$ до часу відновлення весняної вегетації, тим вищою $\epsilon$ залежність рівня врожайності озимої пшениці від строків сівби. За довжини цього періоду понад 30 днів найбільш високу врожай- 
ність формували посіви з сівбою 17 та 25 вересня, а у роки, коли цей період тривав від 10 до 20 днів, вищу врожайність забезпечували посіви 3 сівбою починаючи з 10 вересня по 25 вересня.

У випадку тривалості періоду від дати переходу середньодобової температури повітря через $0{ }^{\circ} \mathrm{C}$ до відновлення весняної вегетації рослин до 20 днів врожайність посівів озимої пшениці 3 ранньою сівбою 2 вересня та пізньою 2 жовтня $\epsilon$ майже однаковою. Так, посіви 3 сівбою 2 вересня за тривалості цього періоду до 10 днів формували врожайність на рівні 5,44 т/га, а посіви 3 сівбою 2 жовтня - 5,56/га. Водночас, якщо тривалість цього періоду перевищує 20 днів, то посіви 3 сівбою 2 жовтня формують значно вищу врожайність, ніж посіви 2 вересня.

Дослідження показують, що у роки з тривалістю періоду $« 0{ }^{0} \mathrm{C} . . .+5{ }^{\circ} \mathrm{C} »$ від 20 до 30 днів посіви 3 сівбою 2 жовтня є більш продуктивними, ніж посіви, сівба яких проведена 2 вересня. $\mathrm{y}$ середньому за роки досліджень врожайність становить відповідно 4,70 та 3,88 т/га.

У цілому характер зміни рівня врожайності різновікових посівів озимої пшениці залежно від довжини періоду переходу від $0{ }^{\circ} \mathrm{C}$ до відновлення вегетації у роки, коли він триває від 20 до 30 днів та роки 3 тривалістю понад 30 днів, можна вважати тотожним. Але все ж таки між ними існують певні відміни. Так, у роки, коли тривалість періоду від $0{ }^{0} \mathrm{C}$ до відновлення весняної вегетації становить 20-30 днів, врожайність пізніх посівів 3 сівбою 2 жовтня $є$ значно вищою, ніж посівів, сівба яких проведена у період з 25 серпня по 10 вересня. У середньому за роки досліджень врожайність посівів 3 сівбою 2 жовтня склала 4,70 т/га проти 2,8-4,37 т/га за сівби у період з 25 серпня по 10 вересня.

У роки, коли тривалість періоду від настання температури $0{ }^{\circ} \mathrm{C}$ до $+5{ }^{\circ} \mathrm{C}$ становить більше 30 днів, врожайність посівів з сівбою до 2 вересня $\epsilon$ значно меншою, ніж посівів із сівбою 2 жовтня,

\section{БІБЛІОГРАФІЯ}

1. Браженко I. П., Гангур В. В., Крамаренко І. В., Чекрізов І. О., Удаденко К. П., Браженко Л. А. Час відновлення весняної вегетації озимої пшениці догляд та продуктивність // Вісник Полтавської державної аграрної академії, 2006. - №1 . - С. 19-26.

2. Мединеи В.Д. О целесообразности пересева пострадавших посевов озимой пшеницы//ерновые и масличные культуры. - 1968. - №2. - С. 13-16.

3. Мединеи В. Д. Прогнозирование и пути повышения качества зерна озимой пшеницы// Зерновые и масличные культуры. - 1968. - №5. - С. 8-11.

4. Мединеи В. Д. Полегание озимой пшеницы и а врожайність посівів 10 вересня та 2 жовтня $€$ майже однаковою і у середньому за роки досліджень становить 4,05 та 3,99 т/га відповідно.

Висновок. Час відновлення весняної вегетації рослин впливає на урожайність посівів озимої пшениці. Чим пізніше відновлюється вегетація, тим меншою $є$ врожайність. За надраннього відновлення вегетації (III декада лютого) врожайність різновікових посівів є майже однаковою і становить від 6,44 до 6,96 т/га. У випадку пізнього відновлення вегетації (початок квітня місяця) найбільш високу врожайність формують посіви 3 сівбою 310 по 25 вересня. Їх врожайність у середньому за роки досліджень склала 3,86-3,91 т/га. За такого терміну відновлення весняної вегетації врожайність посівів 3 сівбою 2 вересня та 2 жовтня $\epsilon$ майже однаковою і становить відповідно 2,99 та 2,88 т/га, але значно більшою за врожайність посівів 3 сівбою 25 серпня.

Чим коротшим $є$ період від переходу температури через $0{ }^{0} \mathrm{C}$ до $+5{ }^{0} \mathrm{C}$, тим більшою $\epsilon$ врожайність озимої пшениці. У середньому за роки досліджень врожайність озимої пшениці в разі тривалості періоду від переходу температури через $0{ }^{\circ} \mathrm{C}$ до $+5{ }^{\circ} \mathrm{C}$ до 10 днів становила $6,04 \mathrm{~T} / \mathrm{ra}$, а при подовженні цього періоду до 30 і більше днів зменшувалася до 3,76 т/га.

У випадку тривалості періоду весняної вегетації від часу настання температури повітря $0{ }^{\circ} \mathrm{C}$ до $+5^{0} \mathrm{C}$ до 20 днів врожайність пізніх посівів із сівбою 2 жовтня є значно меншою, ніж посівів із сівбою 10 вересня. У середньому за роки досліджень врожайність посівів 3 сівбою 2 жовтня становила 4,79 т/га, а посівів з сівбою 10 вересня - 5,63 т/га. За подальшого подовження тривалості цього періоду до 30 днів різниця між врожайністю посівів із сівбою 2 жовтня та 10 вересня зменшується, а у роки, коли тривалість цього періоду перевищує 30 днів, їх врожайність $є$ майже однаковою, і становить 4,05 та 3,99 т/га.

возможные пути его предотвращения // Зерновые и масличные культуры. - 1969. - №1. - С. 24-26.

5. Мединеи В. Д. Весеннее развитие и продуктивность озимых хлебов. - М. : Колос, 1982. $174 \mathrm{c}$.

6. Мостіпан M. I. Залежність врожайності посівів озимої пшениці від рівня їх волого забезпечення у північному Степу України // Матеріали II Регіональної науково-практичної конференції «Екологічні проблеми сучасності та шляхи їх вирішення», Кіровоград. 2016. - С. 102-108.

7. Мостіпан M. I. Поправки до технології // 


\section{СІЛЬСЬКЕ ГОСПОДАРСТВО. РОСЛИННИЦТВО}

Farmer. - K., 2016. - C. 62-66.

8. Мостіпан М. I. Вологозабезпеченість посівів озимої пшениці у весняно-літній період вегетації та їх врожайність в північному Степу України// Науковий збірник «Вісник Степу». - 2017. №14. - С. 77-82.

9. Мостіпан М. І., Савранчук В. В., Ліман П. Б. Виживання рослин та урожайність озимої пшениці залежно від норм висіву в північному Степу України // Матеріали наукової конференції молодих вчених. - Умань, 2005. - С. 55-58.

10. Савранчук В. В. Науково-обгрунтована система ведення агропромислового виробництва в Кіровоградській області / В. В. Савранчук, І. М. Семеняка, Л. П. Пікаш, М. Мостіпан. - Кіровоград, 2005. $-264 \mathrm{c}$.

11. Нетис И. Т. Начало весенней вегетации озимой пшеници и эффективность агроприёмов //

\section{ANNOTATION}

Mostipan M. I., Umrykhin N. L. Winter wheat productivity depending on weather conditions during early spring period in the Northern Steppe of Ukraine.

It has been established that in the Northern Steppe of Ukraine the beginning of spring vegetation of winter wheat starts at different periods of time. The earliest vegetation (February 22) was observed in 1990, and the latest vegetation (April 4) was in 2003. Therefore, it has been suggested to distinguish the very early (the third decade of February) beginning of vegetation, early beginning of vegetation (the first-second decade of March), middle-time vegetation (the third decade of March) and late beginning of vegetation (the first decade of April) of winter wheat. During the whole period of observations from 1986 to 2005, the very early beginning of vegetation was observed during 3 years $(15 \%)$, early vegetation -4 years $(20 \%)$, middle-time vegetation -8 years $(40 \%)$, and late vegetation -5 years $(25 \%)$.

The analysis of winter wheat productivity shows that the later is the beginning of spring vegetation, the less productivity of winter wheat. During the very early spring vegetation in the third decade of February, productivity is twice as large as compared with the late vegetation in the first decade of April. On average, over the years of the study, these indicators were 6.74 and $3.28 \mathrm{t} / \mathrm{ha}$ respectively. In the very early vegetation (the 3rd decade of February), productivity of the mixed-age crops is almost the same and ranges from 6.44 to $6.96 \mathrm{t} / \mathrm{ha}$. During the late vegetation (early April), the highest productivity is formed by the crops sown from the 10th to the 25th of September. Their
Вісник аграрної науки. - 1995. - №5. - С. 61-66.

12. Hemic I. T. Початок весни та догляд за посівами озимої пшениці // Наук. пр. «Управління онтогенезом рослин». - Полтава, 2011. - Вип. 2. -C. 60-62.

13. Савранчук В. В. Мостіпан М. І., Ліман П. Б. Динаміка густоти рослин нових сортів озимої пшениці протягом вегетаційного періоду залежно від строків сівби у північному Степу України // Зб. наук. праць УДАУ, 2004. - №58. - С. 48-56.

14. Савранчук B. B., Мостіпан М. I., Умрихін Н. Л. Продуктивність озимої пшениці залежно від технологічних прийомів вирощування // Вісник Степу. - Кіровоград : Код, 2012. - С. 11-21

15. Савранчук В. В., Мостіпан М. І., Умрихін Н. Л. Весняне підживлення озимини: класичні та альтернативні методи // Агробізнес сьогодні. - ТОВ «Прес-медіа». - 2016. - С. 42-45.

average productivity during the years of the study was 3.86-3.91 t/ha. With this period of spring vegetation, the productivity of crops sown on September 2nd and October 2nd is almost the same and is 2.99 and $2.88 \mathrm{t} / \mathrm{ha}$ respectively, but significantly higher than the productivity of crops sown on August 25th.

For the formation of winter wheat harvest, the change of the average daily temperature above $0{ }^{\circ} \mathrm{C}$ is important, as well as the duration of the period from that time to the beginning of spring vegetation. That is the steady increase in average daily air temperature to more than $+5{ }^{\circ} \mathrm{C}$. The increase in the period of time from the date of the change of the average daily air temperature above $0{ }^{\circ} \mathrm{C}$ to the beginning of spring vegetation causes the decrease in the productivity of winter wheat. During the years when the duration of this period was up to 10 days, the productivity of winter wheat averaged $6.04 \mathrm{t} / \mathrm{ha}$, and during the years with this period of more than 30 days, the productivity decreased to $3.76 \mathrm{t} / \mathrm{ha}$.

The shorter period from the change of the average daily air temperature above $0{ }^{\circ} \mathrm{C}$ to the time of the beginning of spring vegetation, the higher the dependence of the level of winter wheat productivity on the sowing terms. If this period is longer than 30 days, the highest productivity was formed by crops sown on September 17th and September 25th, and during the years when this period lasted from 10 to 20 days, higher productivity was provided by the crops sown from September 10th to September 25th.

With the duration of the period from the date of the change of the average daily air temperature above $0{ }^{\circ} \mathrm{C}$ to the beginning of spring vegetation to 20 days, the productivity of winter wheat crops with 
early sowing on September 2nd and October 2nd is almost the same. The crops sown on September 2nd with the duration of this period up to 10 days formed productivity of $5.44 \mathrm{t} / \mathrm{ha}$, and the crops sown on October $2 \mathrm{nd}-5.56 \mathrm{t} / \mathrm{ha}$. At the same time, if the duration of this period exceeds 20 days, the crops sown on October 2nd form a considerably higher productivity than the crops sown on September 2nd.

Key words: winter wheat, productivity, sowing terms, time of the beginning of spring vegetation, weather conditions. 